Nyssen, J., Petrie, G., Sultan Mohamed, Gezahegne Gebremeskel, Stal, C., Seghers, V., Debever, M., Kiros Meles Hadgu, Billi, P., Mitiku Haile, Demaeyer, Ph., Frankl, A., 2015. Recovery of the historical aerial photographs of Ethiopia in the 1930s. Journal of Cultural Heritage, in press.

\title{
RECOVERY OF THE AERIAL PHOTOGRAPHS OF ETHIOPIA IN THE 1930s
}

Jan Nyssen ${ }^{\mathrm{a},{ }^{*}}$, Gordon Petrie ${ }^{\mathrm{b}}$, Sultan Mohamed ${ }^{\mathrm{c}}$, Gezahegne Gebremeskel ${ }^{\mathrm{c}}$, Valérie Seghers ${ }^{\mathrm{a}}$, Martijn Debever ${ }^{\mathrm{a}}$, Kiros Meles Hadgu ${ }^{\mathrm{d}, \mathrm{e}}$, Cornelis Stal ${ }^{\mathrm{a}}$, Paolo Billi ${ }^{\mathrm{f}}$, Philippe Demaeyer ${ }^{\mathrm{a}}$, Mitiku Haile ${ }^{\mathrm{g}}$, Amaury Frankl ${ }^{\mathrm{a}}$

${ }^{a}$ Ghent University, Department of Geography, Ghent, Belgium

${ }^{b}$ University of Glasgow, School of Geographical \& Earth Sciences, Glasgow, U.K.

${ }^{c}$ Ethiopian Mapping Agency, Addis Ababa, Ethiopia

${ }^{d}$ Mekelle University, Institute of Geoinformation \& Earth Observation Sciences, Mekelle, Ethiopia

${ }^{e}$ World Agroforestry Centre, Addis Ababa, Ethiopia

${ }^{f}$ University of Ferrara, Department of Earth Sciences, Ferrara, Italy

${ }^{g}$ Mekelle University, Department of Land Resources Management and Environmental Protection, Mekelle, Ethiopia

*Corresponding author: jan.nyssen@ugent.be

\section{ABSTRACT}

The aerial photographs (APs) acquired by the Istituto Geografico Militare (IGM) in the period of the Italian occupation of Ethiopia (1935-1941) have recently been discovered, scanned and organised. Until recently, the oldest APs of the country that were available had been taken in the period 1958-1964. The APs over Ethiopia in 1935-1941 consist of 8281 assemblages on approx. $50 \mathrm{~cm}$ x $20 \mathrm{~cm}$ hardboard tiles, each holding a label, one nadir-pointing photograph flanked by two low-oblique photographs and one highoblique photograph. The four APs were exposed simultaneously and were taken across the flight line. The high-oblique photograph is presented alternatively at left and at right. There is approx. $60 \%$ overlap between subsequent sets of APs. One of Santoni's glass plate multi-cameras was used, with focal length of $178 \mathrm{~mm}$ and with a flight height of 4000-4500 $\mathrm{m}$ a.s.1., which resulted in an approximate scale of 1:11,500 for the central photograph and 1:16,000 to 1:18,000 for the low-oblique APs. The surveyors oriented themselves with maps of Ethiopia at 1:400,000 scale, compiled in 1934. The flights present a dense AP coverage of Northern Ethiopia, where they were acquired in 
the context of upcoming battles with the Ethiopian army. Several flights preceded the later advance of the Italian army southwards to the capital Addis Ababa. Further flights took place in central Ethiopia for civilian purposes. As of 1936, the APs were used to prepare topographic maps at 1:100,000 and 1:50,000 scales. To re-process the imagery using novel techniques, procedures using digital image-based modelling have been developed. The 1935-1941 APs together with those of 1958-1964, 1994 and recent high-resolution satellite imagery are currently being used in spatio-temporal analysis, including change studies of land cover, land management and geomorphology in Ethiopia over a time span of 80 years.

Key words: Santoni - IGM - Ethiopian Mapping Agency - historical data conservation of cultural heritage - historical aerial photographs

\section{Research aims}

Nadir-pointing and oblique aerial photographs acquired in the period of the Italian occupation of Ethiopia (1935-1941) have recently been discovered, scanned and organised. Here, we investigate the conditions of the acquisition of the original aerial photography, instrumentation used and subsequent cartographic production. State-ofthe-art technology for the production of ortho-mosaics is evaluated.

\section{Introduction}

The use of airborne photogrammetry took off with the military activities of the first World War, where it was particularly used with the aim of intelligence $[1,2]$. It also became a tool for mapping in industrialised countries in the interwar period. With a few exceptions, before the second World War, the British and French colonial administrations and military cartographic services did not use aerial photography for mapping purposes in Africa [3, 4]. The Dakar area was mapped in 1927 using aerial photographs (APs) [5], as was the inland "delta" of the Niger R. [2] and parts of Senegal in 1929 [6]. Large area coverage of the copperbelt in Northern Rhodesia (now Zambia) was undertaken in the 1920s and 1930s (personal souvenirs GP). In 1929-1930, the boundary zone between British and Italian Somalia was mapped using aerial photographs taken from two British and two Italian airplanes [7]. During the 1930s, large-scale aerial photographs were taken in the then Tanganyika, particularly the 
coastal areas around the city of Dar Es Selam and the island of Zanzibar [8]. In March $1935,11,000 \mathrm{~km}^{2}$ of the western Eritrean lowlands were mapped using aerial photography for which ground signals were established [7]. In South Africa, a decision was made in 1936 to map the country at 1:50,000 and to use aerial photographs for that purpose. The actual aerial photography took only place after the second World War, for which the expertise gained in the war period was very useful [9]. In 1940-1941, the South African Air Force's surveyors supplied aerial photographs that were used to prepare strip maps of important routes in Kenya [9] and Ethiopia [10].

Recently, a large archive of pre-1940 aerial photography has come to light. This collection comprises the coverage of Northern and Central Ethiopia that was acquired during the Italian invasion of the country in 1935-36 and during the period of occupation. This activity ceased after the defeat of the Italian army in East Africa in 1941. The rediscovery of this archive opens new perspectives for change studies as it seems to be the largest set of pre-1940 APs in Africa. For Ethiopia, the oldest APs of the country that are known so far were taken in the period 1958-1964.

\section{Presentation of the archive}

Though the existence of these aerial photographs was well known, both through literature [11] and evidence of its use as basic data to prepare maps in that period (http://www.igmi.org/ancient/) and for geological studies [12], the original photographs themselves could not be accessed for a long time. For instance, at the archives of the Italian Istituto Geografico Militare (IGM) in Firenze only 45 glass plate negatives have been conserved. They cover the town of Addis Ababa and unidentified rural areas and were taken during the years 1935-1936 (pers. comm. Col. Furio Donati). The nearly complete archive of these aerial photographs was re-discovered in 2006 in the basement of the Ethiopian Mapping Agency (EMA) building in Addis Ababa. The APs were stored in ammunition boxes that had belonged to the Italian army, and were left behind when the army withdrew from the city of Addis Ababa in 1941. In total, the archive comprises approximately 34,000 individual photographs, made up of 8281 discrete assemblages, each comprising four adjacent photographs. An individual group or set of four photographs comprises a vertical (nadir-pointing) photograph, flanked by two lowoblique photographs and a single high-oblique photograph, which is present alternatively at left and right (Fig. 1). Photographs bear no fiducials and merely a twoor three-digit identification number. All four photographs had been exposed 
simultaneously in a fan configuration in the cross-track direction (perpendicular to the flight line) to ensure the widest possible angular coverage of the terrain. The vertical and oblique photographs of each successive set of four photographs overlap on the previous set by approximately $60 \%$ in the along-track direction, to ensure stereocoverage of the terrain. The format size of each individual photograph in the archive is $10 \mathrm{~cm} \times 15 \mathrm{~cm}$, though many oblique photographs were slightly cropped on their borders to minimise the seam with the nadir-pointing photographs. Each set of four photographs in the archive had been mounted as an unrectified print laydown, glued on to a 50 x $20 \mathrm{~cm}$ hardboard tile, and identified by a label (Figs. 1 and 2). As a result of an agreement between Ghent University (Belgium), the Ethiopian Mapping Agency (EMA) and Mekelle University (Ethiopia), all the photographs in the archive have been transformed into digital form at the EMA offices in Addis Ababa using a Plustek A3 scanner (Optic Pro A320) with a resolution of 600 spi. Moreover, the scanned photographs have been carefully organised into a searchable inventory.

\section{Acquisition of the original aerial photography}

Northern Ethiopia had only been mapped at a very small scale prior to the Italian invasion through ground surveys conducted along the main routes in the border area by Cap. A. Latini, an Italian officer in civilian clothes, and his team who posed as merchants over a 15 months period. Under that cover, they utilised basic instruments (notebook, compass, altimeter, camera, but no tripod) and came with three-dimensional information of all landscapes they had crossed [7]. In 1934, the IGM (nowadays IGMI) produced a set of maps of northern Ethiopia (http://www.igmi.org/ancient/) that was based on a compilation of earlier maps as well as information from Latini's trajectories. Areas that were hidden to Latini by mountains or escarpments appeared as blank areas on those maps. Thus, very large areas of rugged mountainous terrain lying between Latini's routes were completely unmapped.

The acquisition of the systematic aerial photographic coverage began immediately after the Italian invasion of Ethiopia in October 1935. The main objective of the coverage was to provide the raw material for the rapid production of topographic maps of Northern Ethiopia, and more precisely the border region lying immediately adjacent to Eritrea, the Italian colony from which the main invasion was mounted [7]. The data acquisition was executed by the $7^{\text {th }}$ Topocartographic Section of IGM. 
A three-engined, high-wing Caproni Ca-101 D2 aircraft and a crew were provided by the Italian Royal Air Force (Regia Aeronautica) to undertake the flying of the aerial photographic coverage [7]. Flights were operated systematically, combining both direct military needs and the preparation of topographic map sheets [11]. However, neither flight coordinates were available nor regular flight patterns. The flights were also not linear, sometimes along long-distance trails or rivers. Furthermore, it was extremely difficult to have straight flights in tropical mountainous areas affected by air turbulences.

After the Italian army had occupied Northern Ethiopia, later aerial photographic flights covered the routes leading to the south towards the Ethiopian capital, Addis Ababa, along which the Italian army advanced to capture the city in May 1936. In 1937, most of the Italian $7^{\text {th }}$ topocartographic section was moved from Ethiopia to Spain to assist Franco's army in its war against the Spanish Republic. Latter flights in Ethiopia were undertaken with the aim of establishing colonial infrastructure such as urbanisation (Addis Ababa, Dire Dawa, and Harar), hydropower [13, 14] or major roads such as the one linking Addis Ababa and Bahir Dar that needed to cross the one-kilometre deep Blue Nile gorge. Area-wide coverage was, however, only attained in Tigray where the main battles of the Italo-Ethiopian war took place [7].

In the recovered archive, every set of 4 photographs is accompanied by a label (Fig. 2) that indicates date, serial numbers and locations that were overflown. Many of the names mentioned are small localities that do not appear on any map, except the 1934 series maps at scale of 1:400,000. This tends to indicate that those maps were the ones used for flight planning. Consequently, relocating the position of the aerial photographs is a painstaking exercise in absence of even approximate coordinates and with little infrastructure present on the ground. By 24/2/2015, we could relocate 3084 of the 8281 AP assemblages (Fig. 3). Besides maps and field knowledge, historical works on the Italo-Ethiopian war [15-18] also provided useful information to relocate localities mentioned on the labels.

\section{Instrumentation for aerial photography}

The instrumentation that was used for the acquisition of the aerial photography and the subsequent mapping had been designed by the famous Italian photogrammetrist, Ermenegildo Santoni who, at that time, was employed by IGM at its headquarters in Florence [19]. Prior to the war, in 1933, Santoni had designed his Model II glass-plate 
camera (Fig. 4). The actual cameras were built by Officine Galileo, the well-known Italian optical instrument manufacturer, whose factory was also based in Florence, not far from IGM's headquarters. Each Model II camera comprised two separate cameras coupled together to operate as a single integrated unit. This ensured simultaneous exposures to the left and right of the flight line, with a slight overlap between them. Thus the Model II was a twin camera unit, equipped with two lenses, with each lens having a focal length of $175 \mathrm{~mm}$. The twin cameras used photographic glass plates to record the resulting images in the two separate focal planes, with each negative image being $10 \mathrm{~cm} \times 15 \mathrm{~cm}$ in size. Each of the two rotating cylindrical drum magazines held 200 of these glass plates [7].

For the purposes of "colonial mapping" in Libya and East Africa, where a much wider angular coverage of large areas of terrain in a single set of exposures was required for the purposes of small-scale mapping, Santoni devised a four-coupled version of the Model II camera [20]. This comprised two of the twin camera units coupled together in such a way that each angle between successive lenses was $30^{\circ}$, which led to a coverage with a consistent geometry [7]. Santoni's solar periscope was attached to this combination: an auxiliary camera pointing vertically upwards from the top of the aircraft (Fig. 5). This additional camera exposed images of the Sun on to photographic film at the same instant as the exposures were being made by the terrain-pointing glass plate cameras in the main four-coupled camera unit [7]. Besides the solar camera, the instrument comprised a film holder with feeding apparatus, a magnetic compass, a directional gyroscope, and a statoscope or anaeroid barometer [21]. The resulting solar images and indications from the other instruments in the periscope allowed the determination of the bearing and tilt of the set of four terrain-pointing photographs at the moment of their exposure. This information was used as an aid in the provision of control points through a special form of aerial triangulation [7, 21]. Unfortunately, the films with this information could not (yet) be recovered.

For the Ethiopian campaign, the solar periscope unit was mounted on a tall metal framework which was itself mounted on a metal stand (Fig. 5b). This metal stand allowed the main four-camera unit to be rotated (oscillated or rocked) around its horizontal axis between successive sets of exposures, thus allowing the exposure of the high-oblique photographs alternately to the left and right of the flight line (Fig. 6). Due to the alternating left and right position of the high oblique photographs, these nearly do not overlap. The four-camera unit was installed over a hole that had been cut in the 
floor of the Caproni Ca-101 D2 aircraft to act as the camera window (Fig. 5b). The development of the oscillating four-coupled version of Santoni Model II aerial camera allowed a much wider image coverage, due to which it was possible to fly at lower altitudes [7]. Obviously, this has led to large geometric displacements, particularly at the outer edge of the high oblique photographs, a problem that was considered as secondary to the better resolution of the other photographs [11].

When flown from a height of $4000 \mathrm{~m}$ a.s.1. (2000 m a.g.1.), the average scale of the resulting photographs was approximately 1:11,500 for the central photographs and $1: 13,000$ to $1: 18,000$ for the two low-oblique photographs. However, some flights were operated at higher altitudes - up to $4500 \mathrm{~m}$ a.s.1. (2500 $\mathrm{m}$ above average ground level) - in which case, the scale of the near-vertical photographs would be approximately $1: 14,000$ and the oblique photos correspondingly smaller in scale (resp. 1:16,500 and $1: 28,500)$. Of course, these values could vary considerably across an individual photograph due to relief displacements, given the mountainous character of much of the terrain of Northern Ethiopia (Fig. 5).

\section{Cartographic production}

The topographic maps that resulted from the newly flown aerial photographic campaign were produced very rapidly by the $7^{\text {th }}$ Topocartographic Section. This unit, which was equipped with extensive photographic, photo-mechanical and printing facilities, had been set up prior to the invasion in a specially-built facility located in Asmara, the capital of Eritrea. After the occupation of Ethiopia, IGM premises including a mapping department were established in Addis Ababa [7] which were taken over by British and South African troops after they captured Addis Ababa in 1941 [13]. A part of the Institute's equipment was shipped to the UK in replacement of equipment that had been destroyed by a German bombing raid on the Ordnance Survey premises in Southampton (personal souvenirs GP).

Besides the four-coupled camera units, Santoni had also designed and built a small transportable stereo-plotting instrument called the Stereosimplex [22] (Fig. 7). This was the forerunner of the well-known series of Stereosimplex II, III, G6 and G7 instruments that came into widespread use during the later decades of the $20^{\text {th }}$ Century. Unlike these later instruments, which featured a purely mechanical projection system, this original Stereosimplex was based on optical-mechanical projection [7]. 
Santoni also designed and built two fixed-angle optical rectifiers which eliminated the main angular tilt values of the low-oblique and high-oblique photographs that had been acquired by the four-coupled camera [7]. Because of the Italian army's need for very rapid mapping, the Stereosimplex instruments were not much used initially. However, the rectifiers were used extensively from the start to produce rectified same-scale and enlarged prints from the low- and the high-oblique aerial photographs. Much of the initial mapping was compiled from these prints by first using graphical radial triangulation methods to produce a framework of control points, within which, the planimetric maps were then compiled by tracing off the planimetric detail (roads, trails, rivers, buildings, etc.) from the rectified photographs [7].

Because of the urgency of producing maps from the aerial photography for military use, the resulting maps were initially mainly planimetric in terms of their content. However, topographic characteristics were also added by rough contour lines that were used to show the relative heights, the shape and character of the land forms of the terrain. These form lines were produced by the map compilation staff undertaking the $3 \mathrm{D}$ stereoviewing and interpretation of the photographs using mirror stereoscopes - with the terrain form lines being drawn in to fit the drainage pattern [7]. These rapidly produced maps were supplemented by numerous rectified mosaics. More detailed and more accurate maps at 1:50,000 and 1:100,000 scales were produced later for the same areas, once the Italian army had occupied them and the IGM ground surveyors had access to the actual terrain to establish the required triangulation, to measure ground control points and to record the toponymy [7]. In this way, between November 1935 and May 1936, 32 sheets at 1:100,000 and 36 at 1:50,000 were produced, the scanned versions of which are available at IGMI (http://www.igmi.org/ancient/).

For the first time in this region, elements of the territory had become visible on photographic plates and were fully mapped with high geometric precision. Until the 1930s, the representation of the vast Ethiopian highlands was perceptually distorted by factors of strangeness and remoteness. The produced maps constituted a new tool through which the geospatial data of the region became known by a top view, drawn on the map in their correct relationship to one another [23] what led to increased accessibility, in this case by the conquering Italian soldiers. This technical, intellectual and semantic process of appropriation gave life to landscapes in an unprecedented reliable way. 


\section{Current use of the historical aerial photography}

Spatially explicit studies in which pre-1950 APs are used for environmental studies in Africa south of the Sahara are few. The Ugandan [24, 25] and Sudanese forests [26] were studied with imagery of around 1950. Change studies using aerial photographs concerned forest cover in Cameroon since 1950 [27], and land use in northern Namibia and southern Angola since 1942 [28]. Huge collections of APs regarding Congo are available at the Royal Museum for Central Africa in Tervuren (Belgium) [29], but few geographical studies that made use of it could be retrieved. Pre-1950 aerial photographic coverage at small scale was undertaken over large areas of East and Central Africa by the U.K. Directorate of Overseas Surveys [30] as well as in French West African colonies (personal souvenirs GP), but there is no evidence that these have ever been used in change studies. Given their large scale and early realisation, the historical aerial photographs of Northern and Central Ethiopia have a significant potential for environmental studies in a temporal and spatial perspective, since these data sources show the existence (or absence) of features such as buildings, structures, communication routes, etc. Moreover, these images indicate the state of the land forms, land cover, land use and drainage pattern at the particular point in time when they were taken. This information is invaluable to those concerned with geographical change studies of this particular region.

A few representative examples of the use of these historical APs in Ethiopia include analyses of the land cover change, land use and physical geography (including the hydrology and geomorphology) of the area in comparison with imagery from, for instance, the GeoEye-1 satellite taken in 2005 (Fig. 8). In this AP analysis of the area near Nebelet (Tigray), it appears that there were fewer terraces or lynchets [31] in 1935 (left) on the fields (1), but their edges were better covered (2). The channels $(3,4)$ which are visible in 2005 (right), were only vegetated depressions in 1935. The temporary river (5) was narrower in 1935. Circles indicate two large trees which have passed the test of surviving more than 70 years of substantial changes in the landscape [32]. In another comparative study, the decrease of the level of Lake Hayk between 1936 and 2014 was addressed (Fig. 9).

Lanckriet et al. [33] used APs of 1935 to demonstrate that steep marginal lands were intensely used by smallholder farmers as larger and more level lands were in the hands of feudal lords. Diachronical analysis of land use changes since 1935 have also been undertaken in a 32- $\mathrm{km}^{2}$ area on the western Rift Valley escarpment [34] and in a 18- 
$\mathrm{km}^{2}$ area north of Dessie [35]. There, woodland occupied 5\% of the area in 1936 which is less than the current cover by forest and eucalypt plantations; this observation is in line with observations on historical terrestrial photographs by Crummey [36].

Changes in the towns and cities are more far-reaching. For example, Mekelle, the capital of the regional state of Tigray, has changed from a small "medieval" town to a modern city with more than 200,000 inhabitants. One can easily recognize certain historic buildings on both the 1935 aerial photograph and the Google Earth image from 2012 (Fig. 10). The river network and the pattern of the main roads have remained largely preserved. This particular historical photograph was acquired by the $7^{\text {th }}$ Topocartographic Section on $4^{\text {th }}$ November 1935. On $8^{\text {th }}$ November, the Italian army advanced and occupied the town.

In the absence of functioning Stereosimplex instruments, for current research, imagebased modelling methodologies, pertaining to computer vision science, may be used for restitution of the imagery. These allow producing ortho-mosaics based on series of photographs taken at different angles over the same scenery. Especially the vertical and low oblique photographs in the sets are of prime value for the construction of orthophotographs of Ethiopia in the early $20^{\text {th }}$ Century, since, due to insufficient overlap, the high oblique photographs appeared unsuitable. Using image-based modelling software with Structure from Motion and MultiView Stereo (SfM-MVS) procedures implemented, workflows for development of such ortho-mosaics have been developed and a first model was realised using nine assemblages of three aerial photographs [37]; planimetric RMSE (Root Mean Square Error) of the ortho-mosaics was in the range of 20-30 m. We are aware that the geometric calibration of DeskTop Publishing (DTP) scanners was studied intensively in the 1990s [38] and that various tools exist for minimising the distortions caused by the scanner. Unfortunately, it was not possible to perform such a calibration when the images were scanned. Therefore, it has been assumed that all errors related to the digitation of the aerial photographs are incorporated in the (hypothetical) camera model during the 3D reconstruction, resulting in an overall error budget.

\section{Conclusion and perspectives}

Using Santoni's Model II glass plate multi-cameras, the 7a Sezione Topocartografica acquired aerial photographs during the Italian occupation of Ethiopia (1935-1941), the larger part of which have recently been discovered, scanned and organised. These APs 
are presented as assemblages on hardboard tiles, each holding a label, one nadirpointing photograph flanked by two low-oblique photographs and one high-oblique photograph. The four adjacent APs were exposed simultaneously and were taken across the flight line; there is approx. $60 \%$ overlap between subsequent sets of APs. Approximately 34,000 aerial photographs of 1935-41 exist from Ethiopia. These allow the investigation of past dynamics in land use, land cover, geomorphology, etc., for a period that until now was only accessible from terrestrial photographs. However, in order to produce land use and cover maps, or quantify geomorphic features, orthorectified images are required. As the archive consists of both oblique and vertical aerial photographs, methods of image-based modelling have been developed for the ortho-rectification.

Land use and cover change studies are already undertaken in order to fully understand the environmental changes that have been taking place in the region since 1935 . However, it is expected that the historical APs will also be of direct practical value to the local population. Thus, for example, given that food production is a matter of major concern to all of the communities of Northern Ethiopia [39], it is expected that the information provided by the historical aerial photography - through the resulting comprehension of the changes that have occurred over the past 80 years - can make an important contribution. The planning and implementation of measures such as erosion control, the rehabilitation of land through terracing, improved land management, water conservation, reforestation or crop diversification that are being undertaken in northern Ethiopia [40-42] will benefit from the availability of earlier area-specific information.

\section{Acknowledgements}

The authors acknowledge the invaluable support that has been given by staff of the Ethiopian Mapping Agency (EMA) in the efforts to conserve this unique archive. Ms. Fikir Alemayehu, then MSc student at Mekelle University, hinted the authors about existence and whereabouts of the collection of Italian aerial photographs. Ms. Yetemwork Dejene and Ms. Shewaye carried out the scanning work at EMA. The Italian Mapping Institute (IGMI) and particularly Col. Furio Donato provided useful assistance. Mr. Mike Shand (Glasgow University) made technical drawings and Mr. Sil Lanckriet (Ghent University) orthorectified the Lake Hayk aerial photographs. The manuscript has benefited from the constructive comments by two anonymous reviewers and the editor. 


\section{References}

[1] B. Stichelbaut, The first thirty kilometres of the western front 1914-1918: an aerial archaeological approach with historical remote sensing data, Archaeological Prospection, 18 (2011) 57-66.

[2] J. Guillard, Au service des forêts tropicales - Histoire des Services forestiers français outre-mer, Presses de l'ENGREF, 2010.

[3] P. Collier, How shall Africa be mapped? French and British responses to the needs of colonial mapping, in: 25th International Cartographic Conference, International Cartographic Association, Paris, 2011.

[4] L. Hurault, Aerial photography and map-making, Institut du Transport Aérien, Paris, 1959.

[5] J.-L. Trochain, Rôle de l'aviation dans l'étude des formations végétales et des forêts tropicales, Revue de botanique appliquée et d'agriculture tropicale, 10 (1930) 356-360.

[6] A. Chevalier, L'aviation au service de l'agriculture tropicale et de la géographie botanique, Revue de botanique appliquée et d'agriculture tropicale, 10 (1930) 353356.

[7] IGM, L'Istituto Geografico Militare in Africa Orientale, 1885 - 1937, Istituto Geografico Militare, Roma, 1939.

[8] G. McGrath, The Surveying and Mapping of British East Africa: 1890-1946, Cartographica, 13 (1976) 1-118.

[9] A. Jacobs, H. Smit, Topographic mapping support in the South African military during the 20th Century, Scientia Militaria, South African Journal of Military Studies, 32 (2004) 32-50.

[10] E. Liebenberg, The Springboks in East Africa: The role of 1 SA Survey Company (SAEC) in the East African Campaign of World War II, 1940-1941, in: 26th International Cartographic Conference International Cartographic Association, Dresden, Germany, 2013.

[11] M. Bergaglio, L'impiego dell'aereo nella rilevazione cartografica coloniale durante il conflitto italo-etiopico, in: Atti del convegno Nazionale Cultura cartografica e culture del territorio, 12-13 December 2000, Sassari, Italy, Casa Editrice Brigati Glauco \& Co, Genova, Italy, 2001, pp. 573-585.

[12] G. Merla, E. Minucci, Missione geologica nel Tigrai, Reale Accademia d'Italia, Roma, 1938.

[13] H. Hughes, Inventory of the Addis Abeba photogrammetric office, Advanced Force Survey Directorate, Addis Abeba, 1941.

[14] G.-L. Podestà, Building the empire. Public works in Italian East Africa (19361941), Entreprises et Histoire, 70 (2013) 37-53.

[15] A. Del Boca, The Ethiopian War: 1935-1941, University of Chicago Press, Chicago, 1969.

[16] A. Del Boca, I gas di Mussolini. Il fascismo e la guerra d'Ethiopia, Editori Riuniti, Roma, 1996.

[17] C. Traversi, L'Italia in Africa, Storia della cartografia coloniale Italiana.

Poligrafico dello Stato, Roma, (1964).

[18] R. Gentilli, Guerra aerea sull'Etiopia 1935-1939, EDAI, Firenze, 1992.

[19] W. Schermerhorn, In memoriam. Dr. H.c. Ing. Ermenegildo Santoni (18961970), Photogrammetria, 26 (1970) 37-39. 
[20] F. Maranca, L'activité phototopographique de l'Institut Géographique Militaire Italien, in: Conference of the International Society for Photogrammetry, ISP, Paris, 1934, pp. 225-230.

[21] E. Santoni, Il nuovo periscopio solare Santoni per la triangolazione aerea e l'organizzazione delle prese coloniali, in: 5th International Congress of

Photogrammetry, International Society for Photogrammetry, Roma \& Firenze, 1938, pp. 42.

[22] C. Trombetti, Lo stereosimplex Santoni, in: 5th International Congress of Photogrammetry, International Society for Photogrammetry, Roma \& Firenze, 1938, pp. 126-129.

[23] M.J. Kraak, F.J. Ormeling, Cartography: visualization of spatial data, Guildford Press, New York, 2011.

[24] A. Cahusac, Forest mapping from aerial photographs in Uganda, in: Seventh British Commonwealth Forestry Conference, 1957.

[25] H. Dawkins, The management of natural tropical high forest with special reference to Uganda, Imperial Forestry Institute, Oxford, 1958.

[26] D. Francis, Forest inventory in the Sudan, Sudan Silva, 1 (1959) 49-56.

[27] R. Letouzey, Notice de la carte phytogéographique du Cameroun au 1/500 000, Institut de la cartographie internationale de la végétation, Toulouse, France, 1985.

[28] E. Kreike, Re-Creating Eden: Land Use, Environment, and Society in Southern Angola and Northern Namibia, Heinemann, 2004.

[29] J. Bourgeois, M. Meganck, J. Semey, Almost a century of aerial photography in Belgium. An overview, in: J. Bourgeois, M. Meganck (Eds.) Aerial Photography and Archaeology, Academia Press, Gent, Belgium, 2005, pp. 37-48.

[30] G. McGrath, Mapping for development: the contributions of the Directorate of Overseas Surveys, Cartographica, 20 (1983) 264.

[31] J. Nyssen, Mitiku Haile, J. Moeyersons, J. Poesen, J. Deckers, Soil and water conservation in Tigray (Northern Ethiopia): the traditional daget technique and its integration with introduced techniques, Land Degradation and Development, 11 (2000) 199-208.

[32] A. Frankl, Gully development and its spatio-temporal variability since the late 19th century in the Northern Ethiopian Highlands, in: Department of Geography, Ghent University, Ghent, 2012, pp. 261.

[33] S. Lanckriet, B. Derudder, J. Naudts, H. Bauer, J. Deckers, Mitiku Haile, J. Nyssen, A political ecology perspective of land degradation in the North Ethiopian Highlands, Land Degrad. Develop., (2015) online early view.

[34] M. De Meyere, Tesfaalem Gebreyohannes, A. Frankl, Mitiku Haile, J. Nyssen, Land cover trajectories and runoff response on the Ethiopian Rift Valley escarpment over the last eight decades, Geomorphology, submitted (2015).

[35] Girmay Kassa, D. Crummey, K. Descheemaeker, J. Nyssen, Land degradation and resilience in Wollo from the 1930s onwards, as derived from aerial and terrestrial photographs, in: J. Nyssen, Asfawossen Asrat, F. Dramis, Mohammed Umer (Eds.) Excursion guide to the North Ethiopian Highlands. International Association of Geomorphologists, Regional Conference 2011, Addis Ababa, 2011, pp. 22-29.

[36] D. Crummey, Deforestation in Wollo: process or illusion?, J. Ethiop. Stud., 32 (1998) $1-41$.

[37] M. Jacob, A. Frankl, H. Beeckman, Gebrekidan Mesfin, M. Hendrickx, Etafa Guyassa, J. Nyssen, North Ethiopian afro-alpine tree line dynamics and forestcover change since the early 20th century, Land Degrad. Develop., (2015) online early view. 
[38] E.P. Baltsavias, B. Waegli, Quality analysis and calibration of DTP scanners, International Archives of Photogrammetry and Remote Sensing, XXXI (1996) 13-19. [39] H. Azadi, F. De Rudder, K. Vlassenroot, F. Nega, J. Nyssen, Targeting International Food Aid Programmes: The Case of Productive Safety Net Programme in Tigray, Ethiopia, The Journal of Modern African Studies, (2015) submitted. [40] K. Descheemaeker, J. Nyssen, J. Poesen, D. Raes, M. Haile, B. Muys, S. Deckers, Runoff on slopes with restoring vegetation: A case study from the Tigray highlands, Ethiopia, Journal of Hydrology, 331 (2006) 219-241.

[41] J. Nyssen, J. Poesen, Mitiku Haile, J. Moeyersons, J. Deckers, H. Hurni, Effects of land use and land cover on sheet and rill erosion rates in the Tigray Highlands, Ethiopia, Zeitschrift für Geomorphologie, 53 (2009) 171-197.

[42] J. Nyssen, M. Veyret-Picot, J. Poesen, J. Moeyersons, Mitiku Haile, J. Deckers, G. Govers, The effectiveness of loose rock check dams for gully control in Tigray, Northern Ethiopia, Soil Use and Management, 20 (2004) 55-64.

[43] K. O'Mahoney, The salt trail, Journal of Ethiopian studies, 8 (1970) 147-153.

[44] IGM, Catalogo dal Museo Strumenti dell'Istituto Geografico Militare, Supplemento, IGM, Firenze, 1941.

[45] IGMI, Museo degli Strumenti dell'Istituto Geografico Militare di Firenze, http://www.igmi.org/museo/, consulted on 3/7/2015. 


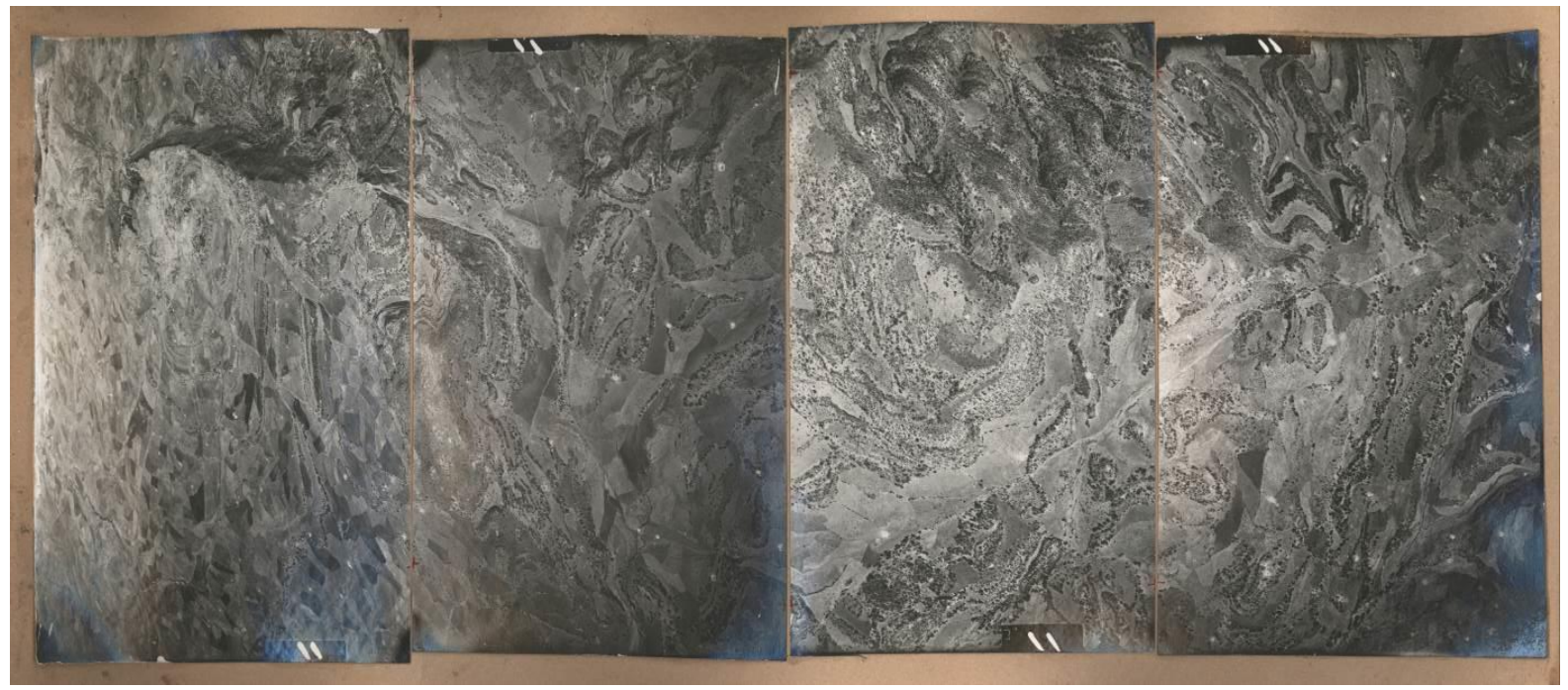

Fig. 1. An example of a set of four photographs comprising - from left to right - high oblique; low oblique; near-vertical; and low oblique exposures in a fan configuration covering an area east of Quiha in Northern Ethiopia. Date: 1935-12-16; Photo number Mai Dolo 11-2-37; centre of the vertical photo at $13.46574^{\circ} \mathrm{N}, 39.59906^{\circ} \mathrm{E}$. () EMA. Width of the conformably oriented fan configuration is $36 \mathrm{~cm}$ on hardboard tile and $6.24 \mathrm{~km}$ on the terrain. Permanent farmland boundaries are clearly visible, as well as bushland that occupies structurally determined scarps. Bright dots correspond to threshing floors. The photographs cover part of the eastern edge of the Ethiopian plateau at approx. $2350 \mathrm{~m}$ a.s.l. Besides a dolerite sill (at left) and structural geomorphological elements (at right), the major WSW-NNE trail used by camel caravans on their way to the Arho salt plains in the Rift Valley (Afar Triangle) [43] assisted in relocating the historical AP.

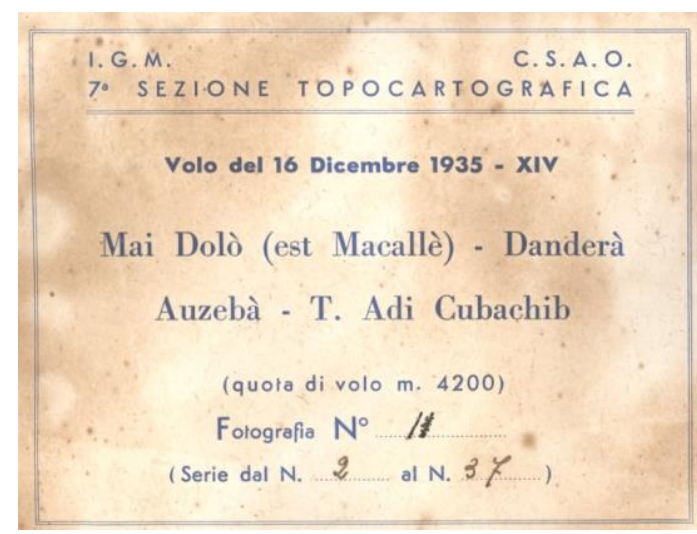

Fig. 2. Label corresponding to the aerial photograph represented in Fig. 1 (@ EMA). The text indicates that the imagery was taken by IGM and CSAO (Comando Superiore dell'Africa Orientale), 7th topocartographic section. Flight date was 16 December 1935, in the 14th year of the fascist calendar (after Mussolini came to power). Approx. flight height was $4200 \mathrm{~m}$. Photograph No. 11 in a series that goes from 2 to 37. Localities overflown were: Mai Dollo (a river to the east of Mekelle), Dandera, Auzeba, T[orrente] Adi Cubachib. 


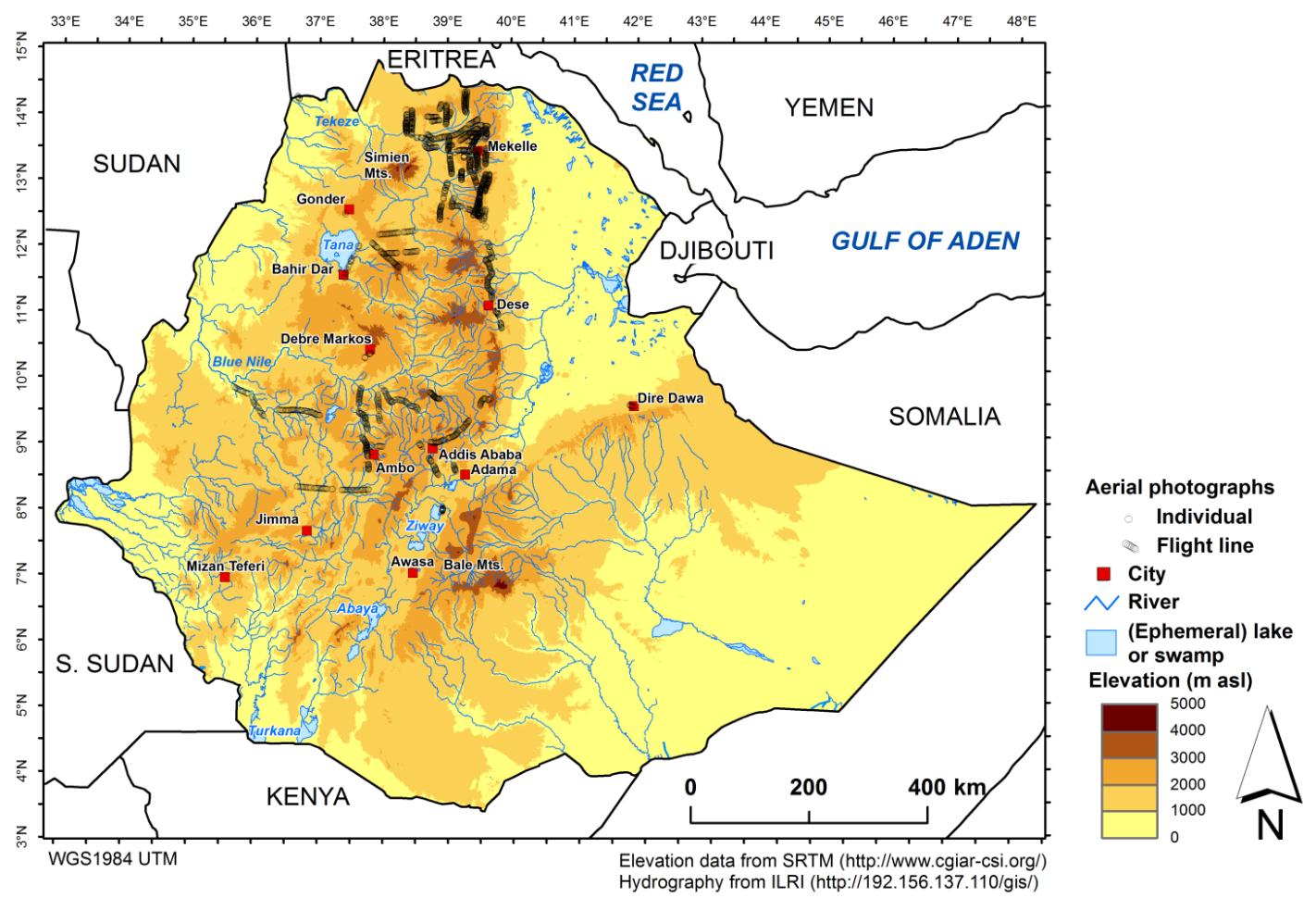

Fig. 3. Location of 3084 relocated aerial photographs of the late 1930s, on 57 different flight lines. Each dot represents the centre of the vertical photograph within an assemblage of four photographs.

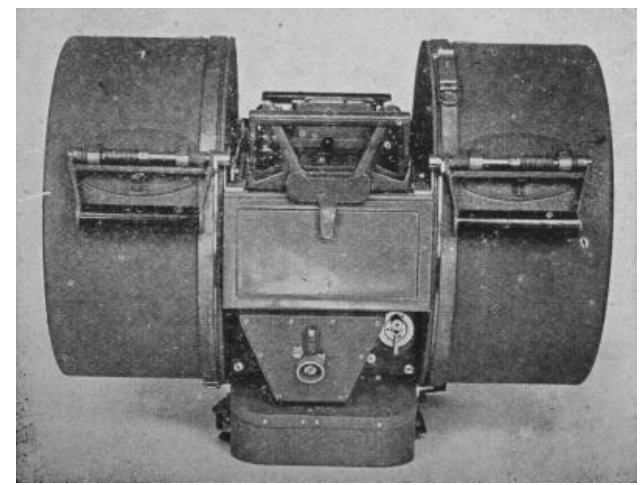

Fig. 4. The Santoni Model II camera with the two rotating drum magazines containing the photographic glass plates mounted on either side of the camera. The twin camera cones with their focal planes, lenses and shutters occupy the space between the two cylindrical drums. [Source: 44, 45]. 
a

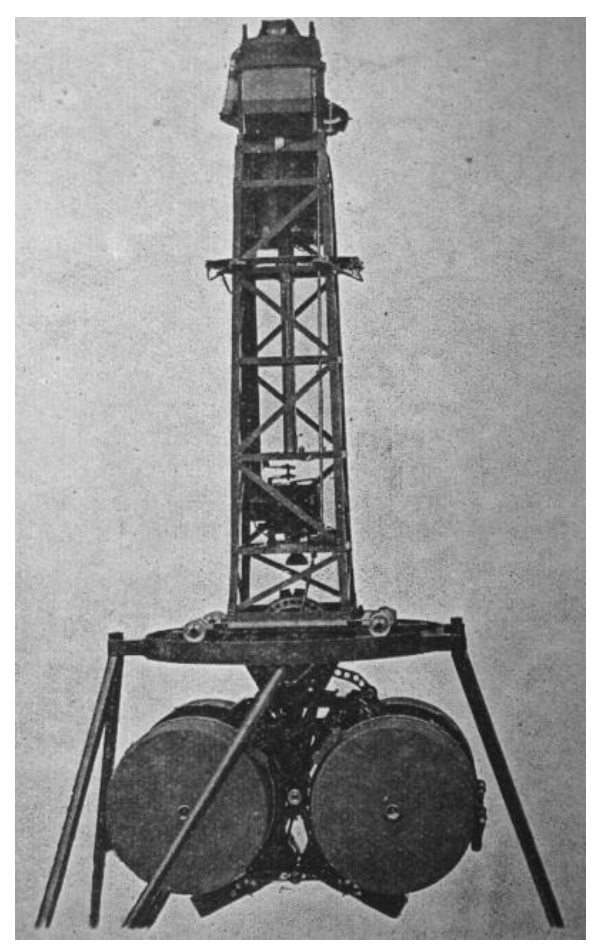

$\mathrm{b}$

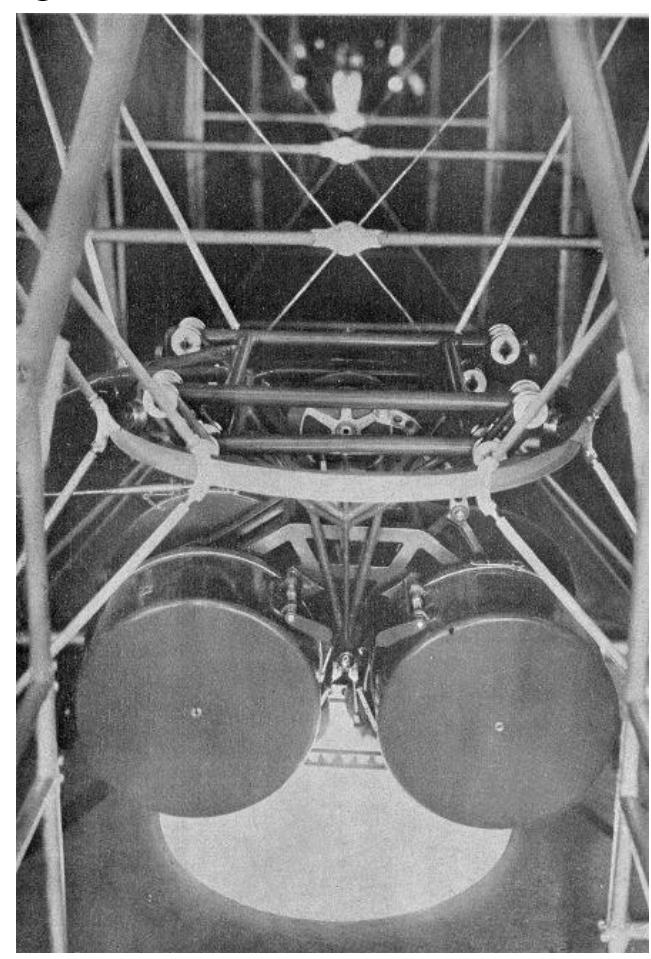

Fig. 5. The four-coupled version of the Santoni Model II camera, (a) complete with its solar periscope at the top [21], and (b) installed over the hole (which acts as the camera window) in the floor of the Caproni Ca-101 D2 photographic aircraft [7]. The metal stand and part of the frame that supported the solar periscope can also be seen.

$\mathrm{a}$

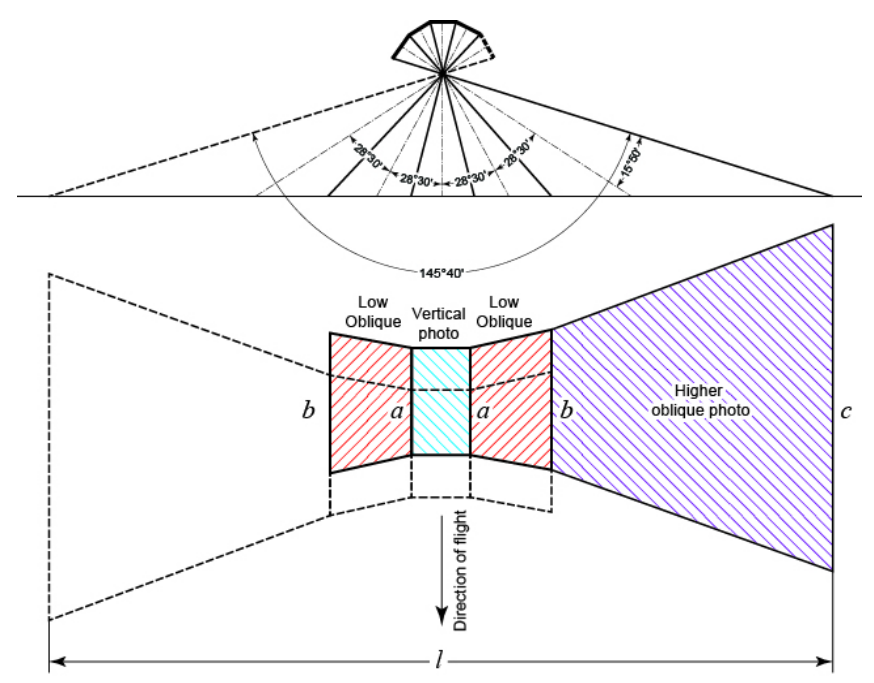

b

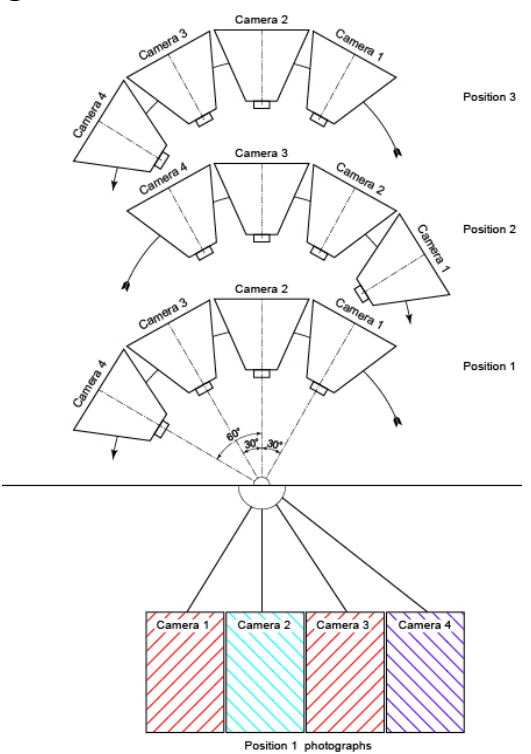

Fig. 6. The four-coupled version of the Santoni Model II camera: (a) the angular (crosstrack) coverage with corresponding ground coverage, and (b) its rotary (oscillating) movement between the successive sets of photographs. (Drawn by Mike Shand, Glasgow University; after IGM [7]) 


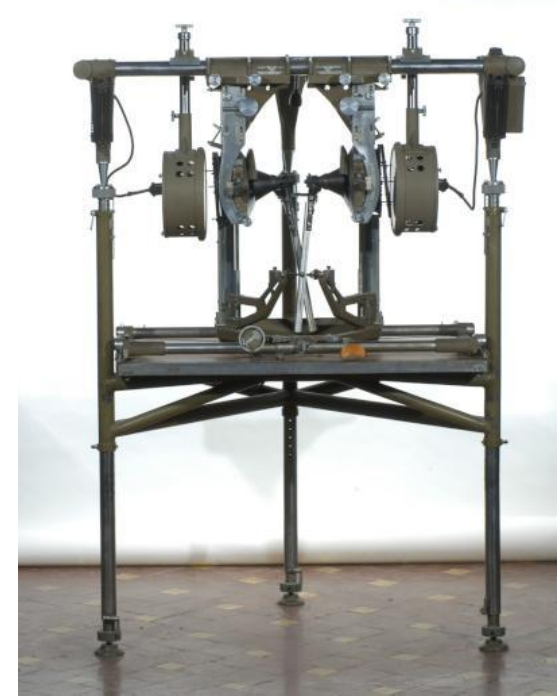

Fig. 7. The transportable Stereosimplex stereo-plotting instrument, which was based on optical-mechanical projection, designed by Santoni and built by Officine Galileo. [Source: 44, 45].

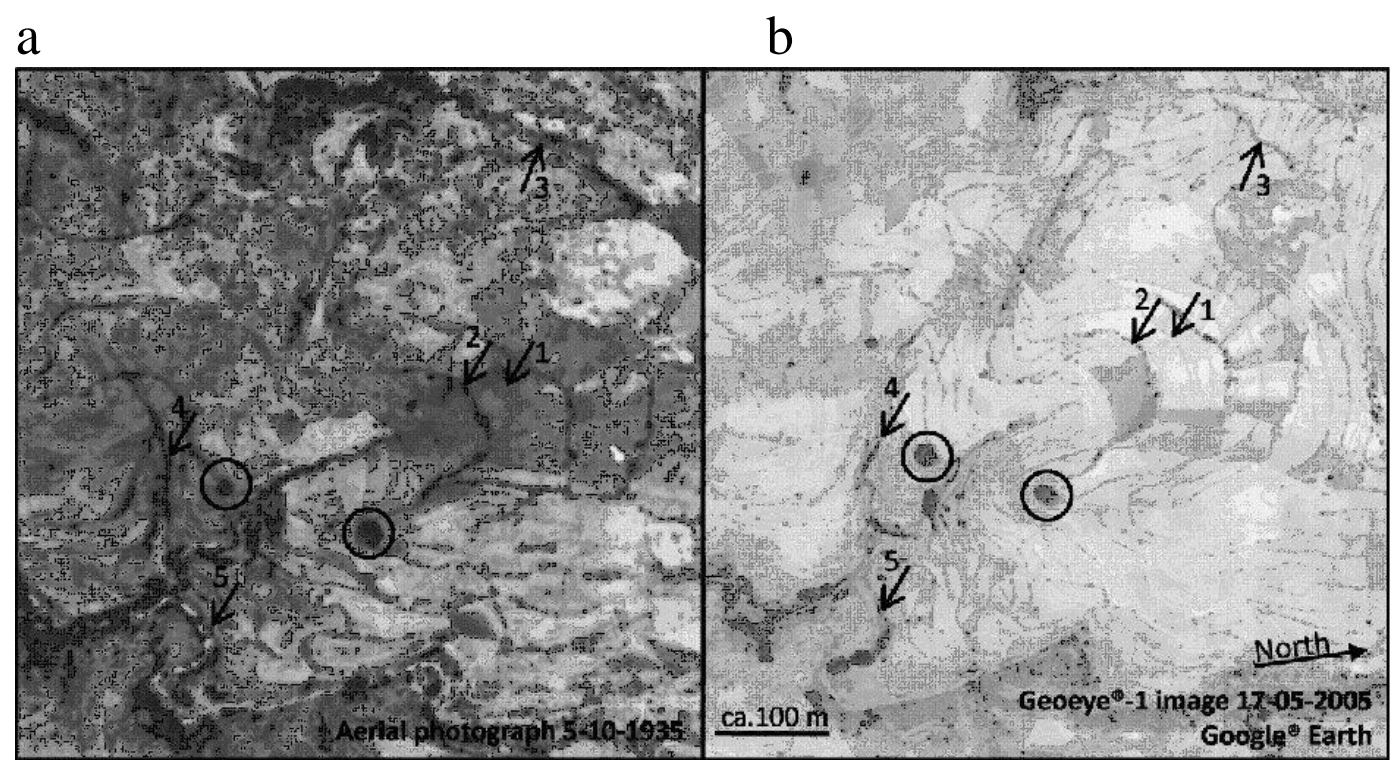

Fig. 8. Comparison of (a) an aerial photograph (C EMA) covering an area near Nebelet (Tigray, Ethiopia), that was acquired in 1935, and (b) the corresponding GeoEye-1 satellite image acquired in 2005 [32]. 
a

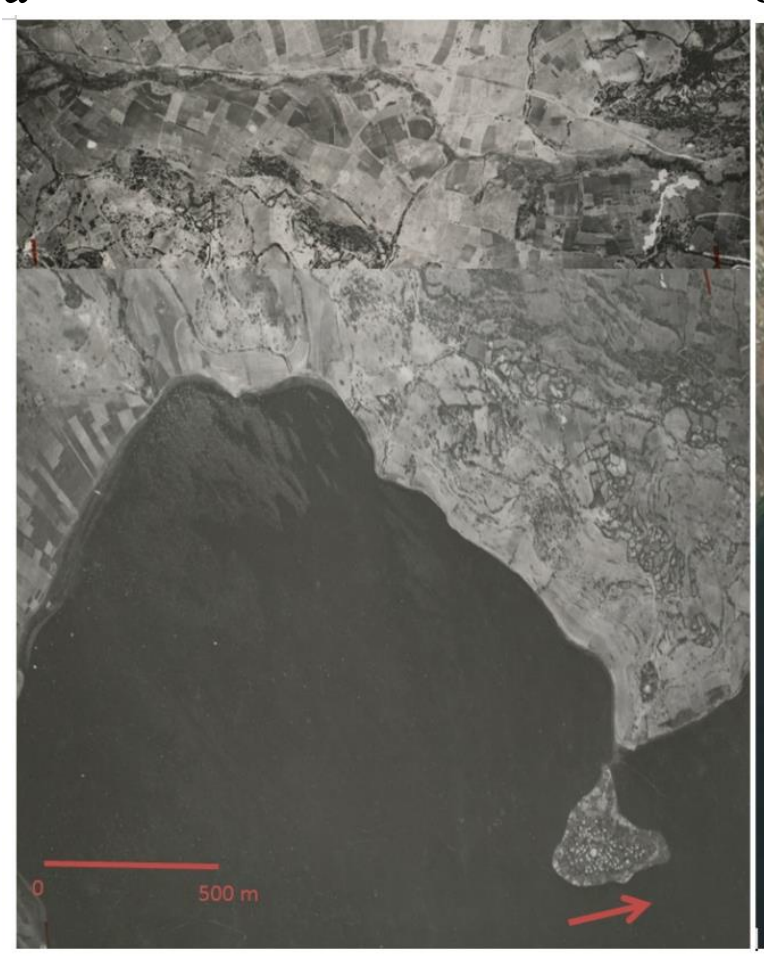

b

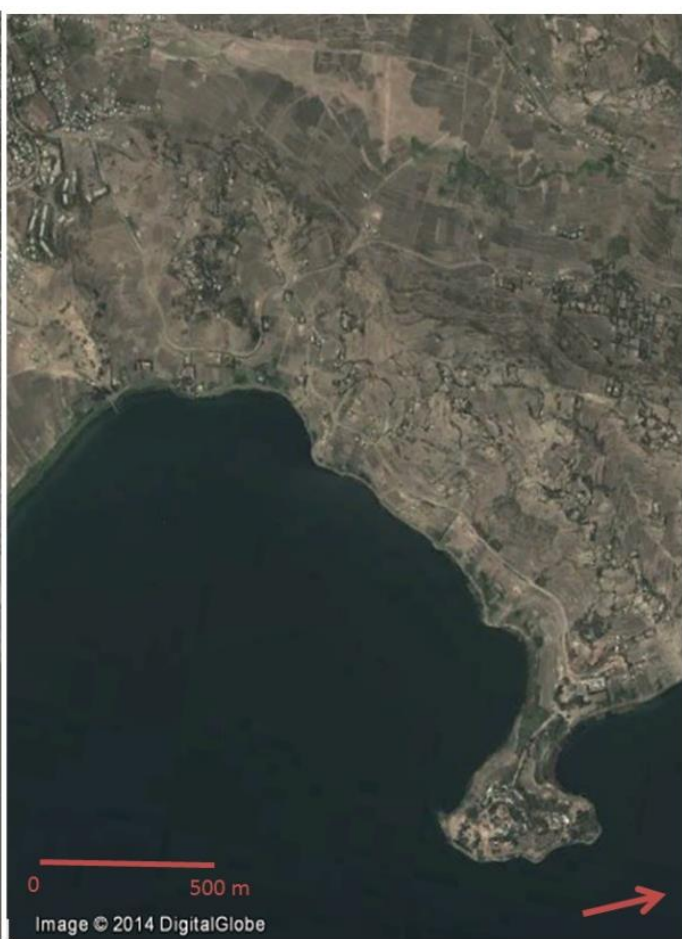

Fig. 9. Western shore of the endorheic Lake Hayk (a) in 1936 (orthorectified aerial photograph, (C EMA) and (b) in 2014. The island (located at $11.33894^{\circ} \mathrm{N}, 39.69735^{\circ} \mathrm{E}$ ) has become a peninsula, due to lowered lake water level. Width of scene is approx. 1.8 $\mathrm{km}$; North is to the right. 

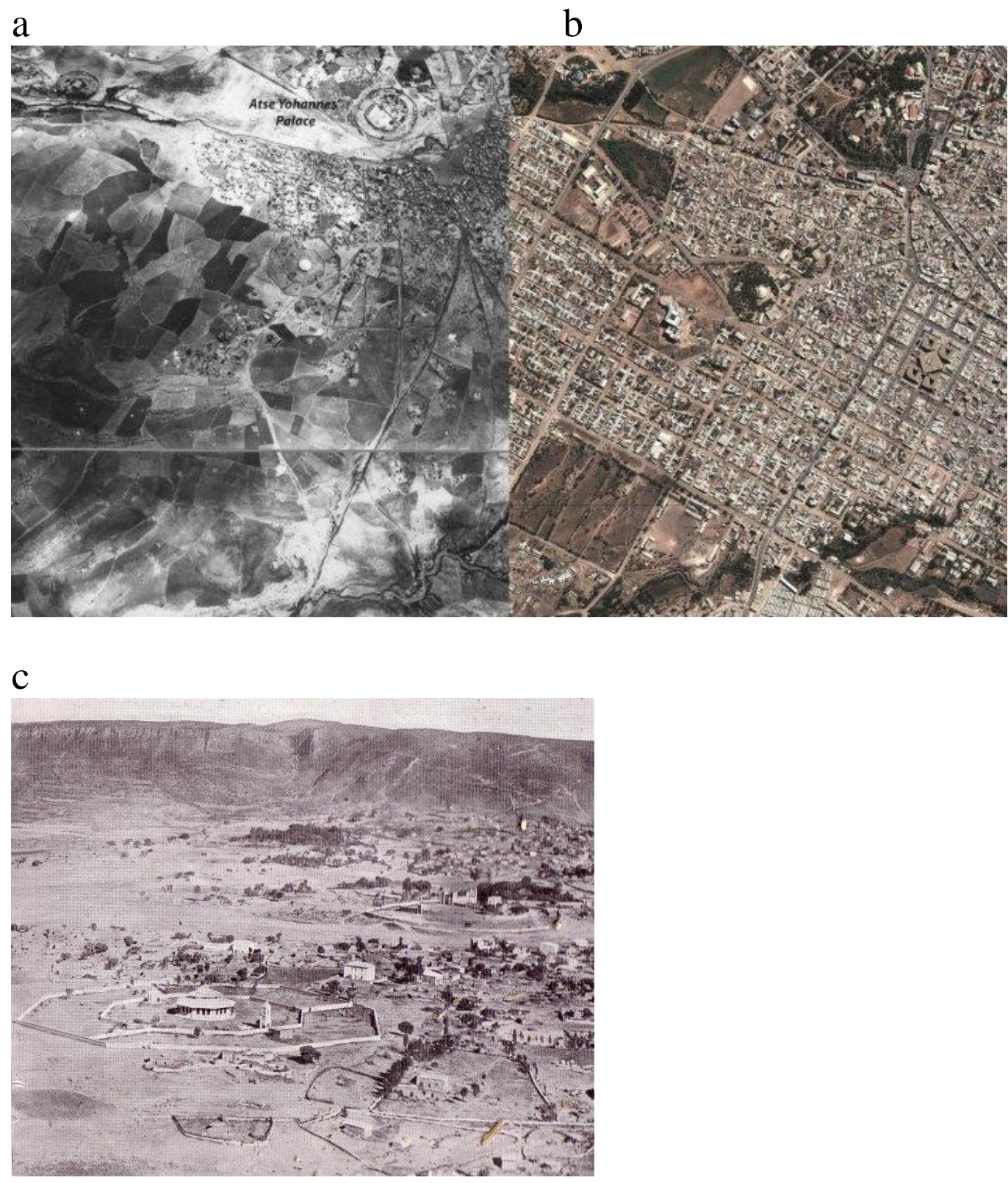

Fig. 10. A comparison of (a) the aerial photograph covering part of the town of Mekelle (Tigray, Ethiopia), that was acquired in 1935 (C EMA), (b) the corresponding Google Earth image of the city that was acquired in 2012, and (c) an oblique aerial photograph of Mekelle taken in 1935 [7] showing the Church of Enda Mariam and the Palace of Atse Yohannes. Both buildings can clearly be seen on the aerial photographs also. The barren slope at the back has been reforested since. 